\title{
Low TSH Congenital Hypothyroidism: Identification of a Novel Mutation of the TSH B-Subunit Gene in One Sporadic Case (C85R) and of Mutation Q49stop in Two Siblings with Congenital Hypothyroidism
}

\author{
AMALIA SERTEDAKI, ANASTASIOS PAPADIMITRIOU, ANTONY VOUTETAKIS, \\ MARIA DRACOPOULOU, MARIA MANIATI-CHRISTIDI, AND \\ CATHERINE DACOU-VOUTETAKIS
}

\begin{abstract}
Laboratory of Molecular Endocrinology, First Department of Pediatrics, Athens University, School of Medicine, Aghia Sophia Children's Hospital, Athens, Greece [A.S., A.V., M.D., M.M.-C., C.D.-V.]; First

Department of Pediatrics, Penteli Children's Hospital, Athens, Greece [A.P.]
\end{abstract}

\begin{abstract}
Isolated congenital hypothyroidism resulting from mutation of the TSH $ß$-subunit gene, has rarely been reported. In the present article, we report a new mutation $(\mathrm{C} 85 \mathrm{R})$ in exon 3 of the TSH B-subunit gene in one sporadic case and the mutation Q49stop in two siblings with congenital hypothyroidism. The novel mutation is a $\mathrm{T}$ to $\mathrm{C}$ transition at codon 85 , resulting in a change of cysteine to arginine (C85R) of the $\beta$-subunit. Because the cysteine residues of all glycoproteins are highly conserved, this mutation is expected to result in conformational changes of the $\beta$-subunit, rendering it incapable to form a functional heterodimer with the $\alpha$-subunit. The second mutation described is a $\mathrm{C}$ to $\mathrm{T}$ transition resulting in a premature stop at codon 49 (Q49stop), leading to the formation of a truncated protein. Although the two siblings reported herein carried the same mutation, they had slightly modified clinical and biochemical phenotype. The mutation C85R and the previously described E11stop have, thus far, exclusively been detected in Greek patients. The
\end{abstract}

\section{ABSTRACT}

Q49stop mutation initially detected in Greek patients was subsequently identified in an Egyptian girl and most recently in two Turkish siblings. These three reports possibly indicate the presence of a mutational hot spot on the TSH $\beta$-subunit gene. Hence, with the novel mutation herein reported, a total of five mutations of the TSH $\beta$-subunit gene are recognized as a cause of low-TSH congenital hypothyroidism worldwide. (Pediatr Res 52: 935940, 2002)
CH, congenital hypothyroidism
TRH, TSH-releasing hormone
$\mathbf{T}_{\mathbf{3}}$, triiodothyronine
$\mathbf{T}_{4}$, thyroxine
CG, chorionic gonadotropin
DGGE, denaturing gradient gel electrophoresis
hCH, human chorionic gonadotropin

Congenital hypothyroidism $(\mathrm{CH})$, caused by mutation of the TSH $\beta$-subunit gene, constitutes a rare genetic disorder, inherited in an autosomal recessive manner (1). TSH is a member of the glycoprotein hormone family, which also includes FSH, LH, and CG. These glycoproteins are heterodimeric molecules consisting of a common $\alpha$-subunit and a hormone specific $\beta$-subunit. The gene encoding for the human TSH $\beta$-subunit is located on the short arm of chromosome 1 (1p13) and consists

Received October 29, 2001; accepted June 18, 2002.

Correspondence: Catherine Dacou-Voutetakis, Pediatric Endocrinologist, A' Pediatric Department, Athens University, Medical School, Aghia Sophia Children's Hospital, Goudi, Athens, Greece; E-mail: adacou@med.uoa.gr

Supported by the Special Account for Research Grants of the University of Athens.

DOI: 10.1203/01.PDR.0000034234.88317.B1 of three exons [GenBank/EMBL Data Bank Accession Number: J03937; (2)]. The first exon is untranslated, whereas the other two encode for a leading peptide of 20 amino acids and a mature peptide of 118 amino acids.

To date, no mutations in the $\alpha$-subunit gene have been identified, whereas four mutations have been identified in the TSH $\beta$-subunit leading to $\mathrm{CH}$. These mutations are located in different areas of the coding region of the gene (Table 1). The first mutation reported was the G29R, in the CAGYC region of exon 2, and was identified in three unrelated Japanese families (3). The second one, E11stop, was identified in two related Greek families (4). A third mutation, the $\mathrm{C} 105 \mathrm{~V}$ in exon 3, was described in two related Brazilian families (5), two unrelated German families $(6,7)$, and in one sporadic case from Belgium (8). More recently, a fourth mutation (Q49stop), was identified 
Table 1. Mutations of the TSH $\beta$-subunit gene in the various populations

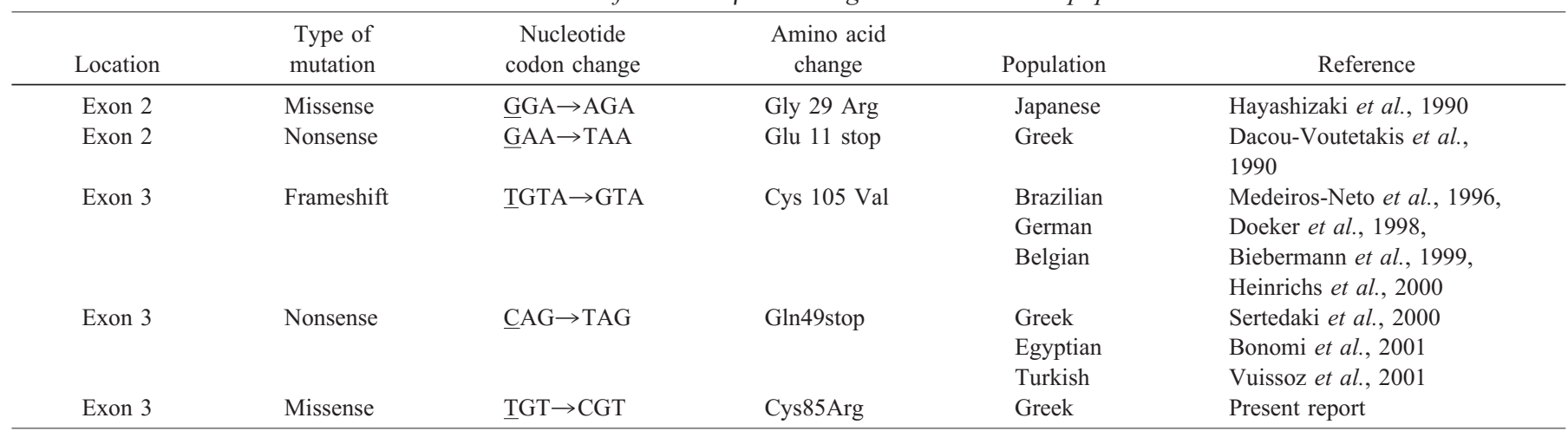

in two Greek siblings with CH (9), one Egyptian girl (10), and two Turkish siblings (11).

In the present article, a novel mutation in exon 3 of the TSH $\beta$-subunit gene in a sporadic case of $\mathrm{CH}$ is reported, and a full description of two siblings with the Q49stop mutation is also presented.

\section{PATIENTS AND METHODS}

\section{Patients}

All three patients have been examined at the Endocrine Unit of the First Pediatric Department, Athens University Medical School. For the special studies, informed consent was obtained and the institutional review board gave approval.

Family $\boldsymbol{A}$. This family has two female children. They live in Athens, but both parents originate from a small Greek island. The first child is normal. The second child was first seen at the Endocrine Clinic at the age of $18 \mathrm{y}$ with a history of taking $\mathrm{T}_{4}$ since the age of 6 mo. The question raised this time was whether or not she was to continue treatment with L-thyroxine. The patient, reportedly, had no prolonged jaundice, omphalocele, or big tongue in infancy. Her uncle, a pediatrician, suspected hypothyroidism, because she slept more than expected and generally she had not the vitality of her older sister at that age. Studies of thyroid function were carried out and she was started on $\mathrm{T}_{4}$. The results of studies before therapy initiation were not available. On physical examination, at age $18 \mathrm{y}$, she looked well, with no clinical stigmata of any kind and was of normal height and weight. She finished high school with average marks. Because the studies before $\mathrm{T}_{4}$ initiation were not available, discontinuation of $\mathrm{T}_{4}$ for $4 \mathrm{wk}$ was advised. At 3 wk, however, the mother thought that the patient was easily fatigued and asked to reinstitute treatment. At this point, thyroid function was evaluated and molecular studies were carried out.

Family B. This family has three children. The parents are of Greek origin but they were born in Taskend, Uzbekistan. The parents denied consanguinity. Nevertheless, they both originate from a small village. The first of their children, a male, is normal. The second, a male, was hospitalized at age $3 \mathrm{wk}$ because of prolonged jaundice. He was delivered at term through a cesarean section because of previous cesarean section. His birth weight was $3500 \mathrm{~g}$ and his length $50 \mathrm{~cm}$. During his hospitalization, it was noted that, besides the jaundice, he also had big tongue and omphalocele. Hypothyroidism was suspected and thyroid evaluation was carried out.

The third child was born after a 34 wk pregnancy, with a birth weight of $2550 \mathrm{~g}$. Immediately after birth, he presented apnoic spells that resulted in a tracheal intubation and was transferred to the intensive neonatal unit. At the age of $3 \mathrm{wk}$, because of prolonged jaundice and the family history of $\mathrm{CH}$, thyroid studies were carried out. No other signs of $\mathrm{CH}$ were present.

\section{Hormonal Studies}

Serum $\mathrm{T}_{3}$, TSH, and prolactin were determined using the microparticle enzyme immunoassay (MEIA) technology (IMX, Abbott Laboratories, Diagnostic Division, Abbott Park, IL, U.S.A.). The total $\mathrm{T}_{3}$ sensitivity was $15 \mathrm{ng} / \mathrm{dL}$ and the intraand intercoefficient of variation were $5.5 \%$ and $6.6 \%$, respectively. The TSH sensitivity was $0.03 \mu \mathrm{IU} / \mathrm{mL}$ and the intraand intercoefficient of variation were $3.8 \%$ and $5.4 \%$, respectively. The prolactin sensitivity was $0.6 \mathrm{ng} / \mathrm{mL}$, and both the intra- and intercoefficient of variation were $3.4 \%$. Serum $\mathrm{T}_{4}$ was determined using the fluorescence polarization immunoassay (FPIA) technology (IMX, Abbott Laboratories). The sensitivity was $1.0 \mu \mathrm{g} / \mathrm{dL}$ and the intra- and intercoefficient of variation was $4.5 \%$ and $2.9 \%$, respectively. The TRH test was carried out after intravenous administration of $250 \mu \mathrm{g}$ of synthetic TRH. Blood samples for TSH determination were obtained before and 30 and $60 \mathrm{~min}$ post TRH.

\section{Molecular Analysis}

DNA was extracted from peripheral blood using the QIAmp DNA Blood Mini Kit (Qiagen GmbH, Hilden, Germany). Exons 2 and 3 of the TSH $\beta$-subunit gene were PCR amplified in two separate reactions. PCR was performed in a $50 \mu \mathrm{l}$ reaction volume containing $100 \mathrm{ng}$ of DNA, $0.2 \mathrm{mM}$ dNTPs, $1.5 \mathrm{mM} \mathrm{MgCl} 2,25 \mathrm{pmol}$ of each primer, $0.05 \% \mathrm{vol} / \mathrm{vol} 1 \%$ $\mathrm{W}-1$, and $1 \mathrm{U}$ Taq DNA polymerase (Invitrogen, Carlsbad, CA, U.S.A.). The following pairs of primers were used: TSH2F: 5'-gATCATATgCATTgggATgg-3' and TSH2R: 5'-TgCgTATCCATTgTgCTgAg-3' for the amplification of exon 2; and TSH3F: 5'-gTCCTgTCACATTATgCTCTC-3' and TSH3R: 5'gCTTTATTTCAggCAAgCAC-3' for the amplification of exon 3 (6). The PCR products were purified by gel electrophoresis followed by agarose gel DNA extraction employing the QIA- 
quick gel extraction kit (Qiagen). The double-stranded PCR products of each exon were directly sequenced using the same primers as for the PCR reaction. In the case of the patient of Family A, the antisense primer of exon 3 (TSH3R) was used for direct sequencing. The Thermosequanase core sequencing kit (Vistra DNA Systems, Amersham Pharmacia Biotech UK, Ltd., Little Chalfont, Buckinghamshire, England) and the Vistra DNA Sequencer 725 (Amersham Pharmacia Biotech UK, Ltd.) were used for sequencing. To verify that the mutations detected in our patients were not polymorphisms, we searched for the presence of these mutations in 60 healthy subjects, using DGGE. For DGGE analysis, exon 3 was amplified and the pair of primers used were: TSH-3: 5'-GCclampAgCTTTATTTCAggCAAgCAC-3' and the primer TSH3R. DGGE was carried out in $8 \%$ acrylamide gel (acrylamide/bis 37.5:1, Genaxis Biotechnology, Nimes, France), the gel gradient was $10-50 \%$ and electrophoresis temperature was $60^{\circ} \mathrm{C}$.

\section{RESULTS}

\section{Hormonal Studies}

Family $\boldsymbol{A}$. In the patient of Family A, the thyroxin value after 3 wk without $\mathrm{T}_{3}$ therapy was $5.1 \mu \mathrm{g} / \mathrm{dL}$ (normal range $5-12.5 \mu \mathrm{g} / \mathrm{dL}$ ). The prolactin value was $16.9 \mathrm{ng} / \mathrm{mL}$ (normal range $<20 \mathrm{ng} / \mathrm{mL}$ ) and the TSH value was $0.1 \mu \mathrm{IU} / \mathrm{mL}$ (normal range: $<5 \mu \mathrm{U} / \mathrm{mL}$ ), with no change 30 and $60 \mathrm{~min}$ after TRH administration (250 $\mu$ g i.v.). The results suggested isolated TSH deficiency, and molecular studies were carried out without further studies of pituitary function (Table 2).

Family B: Patient 1. The serum thyroid hormone values were, for $\mathrm{T}_{4}, 0.003 \mu \mathrm{g} / \mathrm{dL}$ (normal range for infants 1-11 mo: 7.2-15.7 $\mu \mathrm{g} / \mathrm{dL}$ ) and, for $T_{3}, 17.5 \mathrm{ng} / \mathrm{dL}$ (normal range for infants 1-11 mo: $105-245 \mathrm{ng} / \mathrm{dL}$ ). The prolactin value was 77 $\mathrm{ng} / \mathrm{mL}$ (normal range for infants up to $6 \mathrm{wk}:<200 \mathrm{ng} / \mathrm{mL}$ ). TSH was $0.03 \mu \mathrm{IU} / \mathrm{mL}$, with no change 30 and $60 \mathrm{~min}$ after TRH administration $(250 \mu \mathrm{g}$ i.v.). $\mathrm{GH}$ and cortisol values were normal. Isolated TSH deficiency was diagnosed and pertinent molecular studies were carried out.

Family B: Patient 2. The serum thyroid hormone values were, for $\mathrm{T}_{4}, 1 \mu \mathrm{g} / \mathrm{dL}$ (normal range for infants 1-11 mo: 7.2-15.7 $\mu \mathrm{g} / \mathrm{dL}$ ) and, for $\mathrm{T}_{3},<0.15 \mathrm{ng} / \mathrm{dL}$ (normal range for infants 1-11 mo: 105-245 ng/dL). The prolactin value was 123 $\mathrm{ng} / \mathrm{mL}$ (normal range for infants up to $6 \mathrm{wk}:<200 \mathrm{ng} / \mathrm{mL}$ ). The TSH values before and 30 and 60 min after TRH administration (250 $\mu \mathrm{g}$ i.v.) were $4 \mu \mathrm{IU} / \mathrm{mL}, 6 \mu \mathrm{IU} / \mathrm{mL}$, and 5.2 $\mu \mathrm{IU} / \mathrm{mL}$, respectively (Table 2 ).
Family B: parents and healthy brother. The serum thyroid hormone values for the mother were, for $\mathrm{T}_{4}, 6.6 \mu \mathrm{g} / \mathrm{dL}$ (normal range: $5-13 \mu \mathrm{g} / \mathrm{dL}$ ), for $\mathrm{T}_{3}, 92 \mathrm{ng} / \mathrm{dL}$ (normal range: $80-220$ $\mathrm{ng} / \mathrm{dL}$ ), and, for TSH, $1.1 \mu \mathrm{IU} / \mathrm{mL}$ (normal range: $0-5 \mu \mathrm{IU} /$ $\mathrm{mL}$ ). For the father, $\mathrm{T}_{4}$ was $8.1 \mu \mathrm{g} / \mathrm{dL}, \mathrm{T}_{3}$ was $126 \mathrm{ng} / \mathrm{dL}$, and TSH was $2.0 \mu \mathrm{IU} / \mathrm{mL}$. For the healthy brother, $\mathrm{T}_{4}$ was 9.6 $\mu \mathrm{g} / \mathrm{dL}, \mathrm{T}_{3}$ was $127 \mathrm{ng} / \mathrm{dL}$, and TSH was $1.9 \mu \mathrm{IU} / \mathrm{mL}$.

Molecular studies were carried out without any further studies of pituitary function.

\section{Molecular Studies}

Direct sequencing of exons 2 and 3 of the TSH $\beta$-subunit gene, in all patients and their parents, revealed two mutations in exon 3 , one in each of the families studied.

The propositus from family A (Fig. $1 A$ ) was found to be homozygous for a $\mathrm{T}$ to $\mathrm{C}$ transition resulting in a change of cysteine to arginine at codon 85 (C85R) (Fig. 1C and Fig. 3). Both clinically normal parents were found heterozygotes for the mutation (Fig. $1 B$ and Fig. 3). The sister of the patient of family $\mathrm{B}$, denied molecular evaluation. She is clinically completely normal.

The two siblings of family B (Fig. $2 A$ ) were found to be homozygotes for a $\mathrm{C}$ to $\mathrm{T}$ transition, resulting in a premature stop at codon 49 (Fig. 2D). The unaffected parents were found to be heterozygotes for this mutation (Fig. 2C), whereas the patients' brother was found to have normal alleles (Fig. $2 B$ ).

None of the 60 normal controls tested was found to carry any of the two mutations described above.

\section{DISCUSSION}

With the new mutation herein reported, a total of five mutations of the TSH $\beta$-subunit gene have been identified as a cause of low TSH hypothyroidism worldwide. The G29R mutation in the CAGYC region of exon 2 of the gene was identified in three unrelated Japanese families, suggesting that there may be a single founder in this population (3). The $\mathrm{C} 105 \mathrm{~V}$ mutation has been identified in two related Brazilian (5) and two unrelated German families $(6,7)$ as well as in one sporadic case from Belgium (8). The frequency of this mutation suggests that cysteine 105 represents a mutational hot spot. This mutation so far has not been detected in any patient with low TSH hypothyroidism of Hellenic origin.

Thus far, three different mutations have been identified in the Hellenic population (Table 1): the two mutations E11stop (4) and Q49stop (9-11) previously reported, and the new mutation

Table 2. Pertinent hormonal data

\begin{tabular}{|c|c|c|c|c|c|c|c|c|}
\hline \multirow[b]{2}{*}{ Family } & \multirow[b]{2}{*}{ Case } & \multirow{2}{*}{$\begin{array}{c}\text { Age at } \\
\text { diagnosis }\end{array}$} & \multirow[b]{2}{*}{$\mathrm{T} 4 \mu \mathrm{g} / \mathrm{dL}$} & \multirow[b]{2}{*}{ T3 ng/dL } & \multirow[b]{2}{*}{$\operatorname{Prl} n g / m L$} & \multicolumn{3}{|c|}{ TRH TSH $\mu \mathrm{IU} / \mathrm{mL}$} \\
\hline & & & & & & $0^{\prime}$ & $30^{\prime}$ & $60^{\prime}$ \\
\hline$A^{*}$ & 1 & $6 \mathrm{mo}$ & 5.1 & - & 16.9 & 0.1 & 0.1 & 0.1 \\
\hline B & 2 & $3 \mathrm{wk}$ & 1 & 0.15 & 123 & 4 & 6 & 5.2 \\
\hline \multirow[t]{3}{*}{ Normal range } & & & Adults: $5-12.5$ & Adults: $80-220$ & Adults: $<20$ & $0-5$ & & \\
\hline & & & Infants $1-11$ & Infants $1-11$ & Infants up to & & & \\
\hline & & & mo: $7.2-15.7$ & mo: $105-245$ & $6 \mathrm{wk}:<200$ & & & \\
\hline
\end{tabular}

* Hormonal data at re-evaluation aged 16 years. 
A

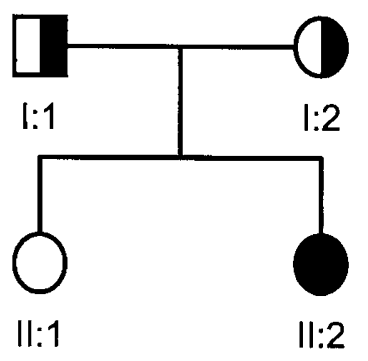

TSH-B exon3

B

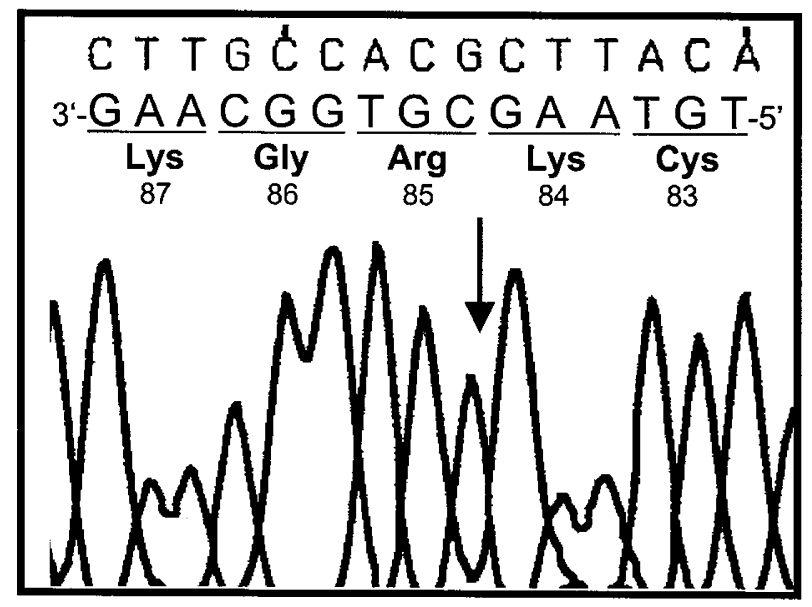

C

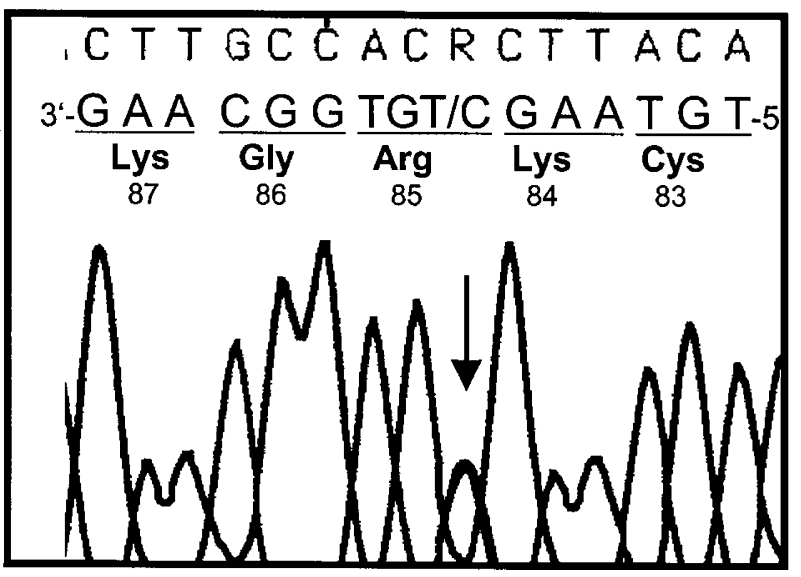

Figure 1. Mutation Cys85Arg. Pedigree of family A $(A)$ and partial sequence of exon 3 of the TSH $\beta$-subunit gene ( $B$ : homozygous patient; $C$ : heterozygous parents) showing the $\mathrm{T} \rightarrow \mathrm{C}$ transition at nucleotide 305 resulting to a missense mutation (Cys $\rightarrow \mathrm{Arg}$ ) at codon 85 of the mature peptide. The $3^{\prime}$ to $5^{\prime}$ antisense PCR primer $(T S H 3 R)$ was used for direct sequencing of exon 3 , and the sequence presented is the $3^{\prime}$ to $5^{\prime}$ strand (top line). Part of the $5^{\prime}$ to $3^{\prime}$ strand sequence is shown (bottom line).

C85Rdescribed in the present article. This new mutation constitutes a $\mathrm{T}$ to $\mathrm{C}$ transition and results in the loss of the ninth cysteine residue $(\mathrm{C} 85 \mathrm{R})$ of the mature peptide. Cysteine 85 forms a disulfide bond with cysteine 31 (12), which constitutes one of the six disulfide bonds formed between the 12 cysteine residues in all glycoprotein hormones. These disulfide bonds
A

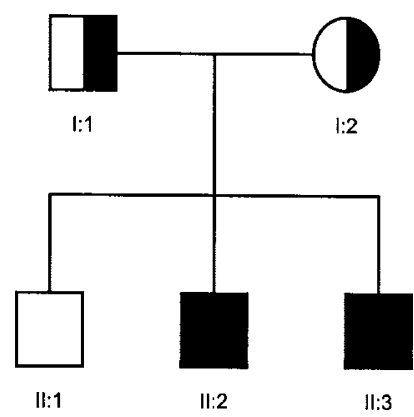

TSH-B exon3

B

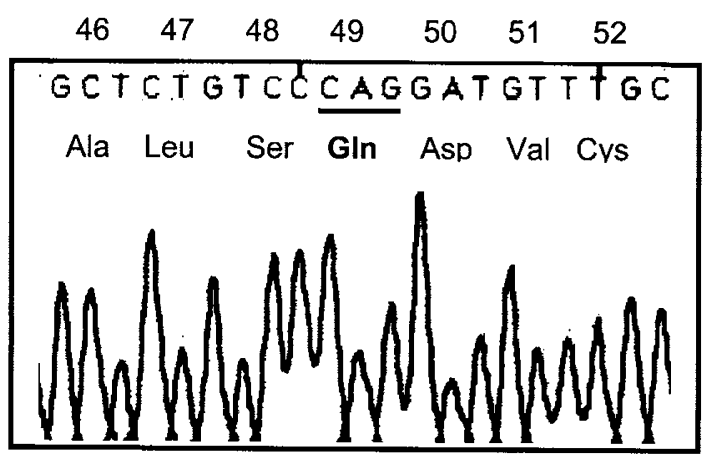

C

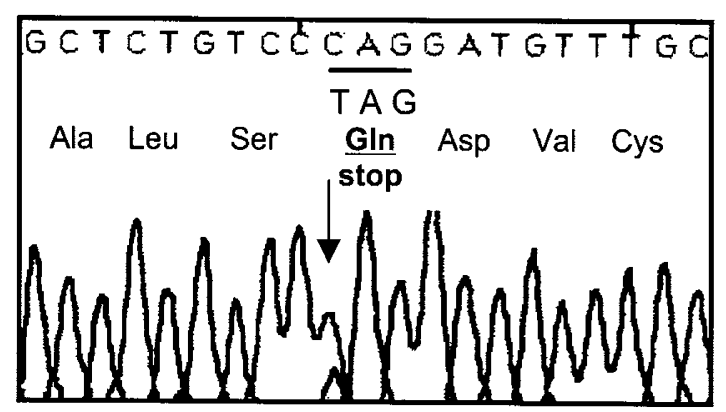

D

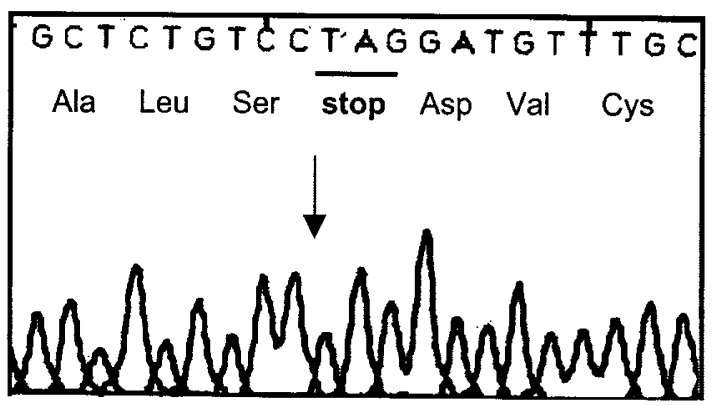

Figure 2. Mutation Q49X. Pedigree of family B $(A)$ and partial sequence of exon 3 of the TSH $\beta$-subunit gene $(B-D)$, showing the $\mathrm{C} \rightarrow \mathrm{T}$ transition at nucleotide 205, resulting to a nonsense mutation (Gln $\rightarrow$ stop) at codon 49 of the mature peptide. $B$ : partial sequence of normal allele. $C$ : partial sequence of heterozygous parents. $D$ : partial sequence of the homozygous patients (patients 1 and 2).

are conserved and located in identical positions in all glycoprotein hormones (13). A disulfide bond is a covalent linkage formed between two cysteine residues to produce a cystine 
Figure 3. DGGE analysis of exon 3 of the TSH $\beta$-subunit gene for family A (ethidium bromide stained DGGE $8 \%$ polyacrylamide gels). Both parents are heterozygotes for the mutation C85R (four bands each on the DGGE gel). $F$, father; $M$, mother; $P 1$, propositus 1 homozygote for the mutation $\mathrm{C} 85 \mathrm{R}$ (one band on the DGGE gel).

residue and contributes to the stability of the three-dimensional shape of the protein molecule. Many disulfide bonds are found in proteins that are secreted by cells, and it is thought that these strong, covalent bonds help stabilize the structure of proteins and prevent them from becoming denatured in the extracellular environment. The fact that the $\beta$-subunits of TSH, CG, $\mathrm{LH}$, and FSH interact with one common $\alpha$-subunit implies that the $\beta$-subunits of these hormones adopt similar conformations, which are most likely determined by the 12 cysteine residues (14). It can therefore be deduced that, in our patient with isolated $\mathrm{CH}$ resulting from the mutation $\mathrm{C} 85 \mathrm{R}$ of the TSH $\beta$-subunit gene, the conformation of the TSH $\beta$-subunit is altered and, consequently, a heterodimer with the $\alpha$-subunit cannot be formed, or an unstable heterodimer results.

Furthermore, cysteine 85 residue is also important for the formation of a significant structural feature such as the cystine knot, which is required for the binding to the TSH receptor (15). The crystal structure of hCG has revealed that three disulfide bonds of the molecule-Cys34-Cys88, Cys38-Cys90, and Cys9-Cys57-are arranged in a cystine knot structural motif (16). The disulfide bond Cys31-Cys85 of TSH ß-subunit corresponds to Cys34-Cys88 disulfide bond of hCG (12). Therefore, Cys- 85 of the TSH $\beta$-subunit is a residue that is also necessary for the binding to the receptor.

Confirmatory evidence that this mutation is the cause of $\mathrm{CH}$ in our case is derived from the fact that this mutation was not identified in 60 control subjects.

The Q49X mutation detected in family B has also been identified in one Egyptian girl (10) and two Turkish siblings (11), possibly indicating the presence of a second mutational hot spot of the TSH $\beta$-subunit gene. This $\mathrm{C}$ to $\mathrm{T}$ transition results in a premature stop at codon 49 of the mature peptide of the TSH $\beta$-subunit, leading to the formation of a truncated protein. Hence, more than half of the mature peptide is missing. This area (amino acids 50-118) includes the BL3 loop, most of the ßsheet, the seat belt, and the carboxyl-terminal. It can therefore be postulated that inasmuch as functionally important residues for the TSH heterodimer formation are miss- ing, no TSH is synthesized. The finding of measurable TSH in one of the siblings with the Q49X mutation and the milder stigmata in this case are difficult to interpret.

The phenomenon of diversity in phenotypic expression observed in the two siblings of family B has also been observed in the case of mutation $\mathrm{C} 105 \mathrm{~V}$, in which one of the cysteine residues of the TSH $ß$-subunit is lost. More specifically, certain patients of the same kindred, homozygotes for the mutation $\mathrm{C} 105 \mathrm{~V}$, had measurable TSH levels and the response to TRH was variable [a 3- to 15-fold rise; (5)], whereas other patients carrying the same mutation had undetectable TSH concentrations, even after TRH stimulation (6).

The phenomenon of variability of clinical or biochemical expression of an identical mutation is not unique to this monogenic disorder. Examples of variability in phenotypic expression of an identical mutation have also been described in other monogenic disorders like congenital adrenal hyperplasia $(17,18)$ and Prop1 gene defects $(19,20)$.

It must be stressed that reports on defects of the TSH $\beta$-subunit gene as a cause of $\mathrm{CH}$ are quite rare. This is not easily explained. Is it really such a rare genetic defect or does it escape identification as a cause of $\mathrm{CH}$ ? The increasing rate of reports for the past few years makes the latter explanation more plausible.

The available data indicate that, in a newborn with low TSH hypothyroidism and normal basal values of cortisol, GH, gonadotrophins, and prolactin and with no response to TRH, the possibility of a genetic disorder involving TSH $\beta$-subunit is quite high and confirmatory molecular studies should be carried out. In such cases, the value of the $\alpha$-subunit is expected to be normal or high, and could theoretically help in the initial diagnostic orientation. Nevertheless, this methodology is not widely available and fails to identify the specific defect involved, so that further molecular studies will still be needed. The exact molecular diagnosis is mandatory for the delineation of prognosis, for genetic counseling, and for the avoidance of laborious dynamic tests of pituitary function in such a delicate developmental stage.

During the revision process of our paper, a sixth mutation of the TSH $\beta$-subunit gene was described. It is a $\mathrm{G}$ to $\mathrm{A}$ transition at position +5 of the donor splice site of intron 2 causing exon skipping (21).

\section{REFERENCES}

1. Miyai K, Azukizawa M, Kumahara Y 1971 Familial isolated thyrotropin deficiency with cretinism. N Engl J Med 285:1043-1048

2. Hayashizaki Y, Miyai K, Kato K, Matsubara K 1985 Molecular cloning of the human thyrotropin- $\beta$ subunit gene. FEBS Lett 188:394-400

3. Hayashizaki Y, Hiraoka Y, Tatsumi K, HashimotoT, Furuyama JI, Miyai K, Nishijo K, Matsuura M, Kohno H, Labbe A, Matsubara K 1990 Deoxyribonucleic acid analyses of five families with familial inherited thyroid stimulating hormone deficiency. J Clin Endocrinol Metab 71:792-796

4. Dacou-Voutetakis C, Feltquate DM, Drakopoulou M, Kourides IA, Dracopoli NC 1990 Familial hypothyroidism caused by a nonsense mutation in the thyroidstimulating hormone $\beta$-subunit gene. Am J Hum Genet 46:988-993

5. Medeiros-Neto G, Herodotou DT, Rajan S, Kommareddi S, de Lacerda L, Sandrini R, Boguszewski CS, Hollenberg AN, Radovick S, Wondisford FE 1996 A circulating biologically inactive thyrotropin caused by a mutation in the beta subunit gene. J Clin Invest 97:1250-1256

6. Doeker BM, Pfäffle RW, Pohlenz J, Andler W 1998 Congenital central hypothyroidism due to a homozygous mutation in the thyrotropin $\beta$-subunit gene follows an autosomal recessive inheritance. J Clin Endocrinol Metab 83:1762-1765 
7. Biebermann H, Liesenkötter KP, Emeis M, Obladen M, Grûters A 1999 Severe congenital hypothyroidism due to a homozygous mutation of the BTSH gene. Pediatr Res 46:170-173

8. Heinrichs C, Parma J, Scherberg NH Delange F, Van Vliet G, Duprez L, Bourdoux P, Bergmann P, Vassart G, Refetoff S 2000 Congenital central isolated hypothyroidism caused by a homozygous mutation in the TSH-beta subunit gene. Thyroid 10:387-391

9. Sertedaki A, Papadimitriou A, Voutetakis A, Dracopoulou M, Dacou-Voutetakis C 2000 Congenital hypothyroidism (CH) caused by a new genetic defect of the thyrotropin (TSH) $\beta$-subunit gene associated with different hormonal derangement in the same sibship. Horm Res 53:11

10. Bonomi M, Proverbio MC, Weber G, Chiumello G, Beck-Peccoz P, Persani L 2001 Hyperplastic pituitary gland, high serum glycoprotein hormone $\alpha$-subunit, and variable circulating thyrotropin (TSH) levels as hallmark of central hypothyroidism due to mutations of the TSHß gene. J Clin Endocrinol Metab 86:1600-1604

11. Vuissoz JM, Deladoëy J, Buyukgebiz A, Cemeroglu P, Gex G, Gallati S, Mullis PE 2001 New autosomal recessive mutation of the TSH- $\beta$ subunit gene causing central hypothyroidism. J Clin Endocrinol Metab 86:4468-4461

12. Fairlie WD, Stanton PG, Hearn MTW 1996 The disulphide bond structure of the thyroid-stimulating hormone $\beta$-subunit. Biochem J 314:449-455

13. Grossmann M, Weintraub BD, Szkudlinski MW 1997 Novel insights into the molecula mechanisms of human thyrotropin action: structural, physiological and therapeutic implications for the glycoproteins hormone family. Endocr Rev 18:476-501

14. Pierce JG, Parsons TF 1981 Glycoprotein hormones: structure and function. Ann Rev Biochem 50:465-495
15. Vitt UA, Hsu SY, Hsueh AJW 2001 Evolution and classification of cystine knotcontaining hormones and related extracellular signaling molecules. Mol Endocrinol 15:681-694

16. Lapthorn AJ, Harris DC, Littlejohn A, Lustbader LW, Canfield RE, Machin KJ, Morgan FJ, Isaacs NW 1994 Crystal structure of human chorionic gonadotropin. Nature 369:455-461

17. Krone N, Braun A, Roscher AA, Knorr D, Schwarz HP 2000 Predicting phenotype in steroid 21-hydroxylase deficiency? Comprehensive genotyping in 155 unrelated, well defined patients from southern Germany. J Clin Endocrinol Metab. 2000 85:10591065

18. Dracopoulou-Vabouli M, Maniati-Christidi M, Dacou-Voutetakis C 2001 The spectrum of molecular defects of the CYP21 gene in the Hellenic population: variable concordance between genotype and phenotype in the different forms of congenital adrenal hyperplasia. J Clin Endocrinol Metab 86:2845-2848

19. Voutetakis A, Livadas S, Sertedaki A, Maniati-Christidi M, Dacou-Voutetakis C 2001 Insufficient adrenarche in patients with combined pituitary hormone deficiency caused by Prop1 gene defect. J Pediatr Endocrinol Metab 14:1107-1111

20. Flück C, Deladoëy J, Rutishauser K, Eblé A, Marti U, Wu W, Mullis PE 1998 Phenotypic variability in familial combined pituitary deficiency caused by a PROP 1 gene mutation resulting in the substitution of Arg to Cys at codon 120 (R120C). J Clin Encocrinol Metab 83:3727-3734

21. Pohlenz J, Dumitrescu A, Aumann U, Koch G, Melchior R, Prawitt D, Refetoff S 2002 Congenital secondary hypothyroidism caused by exon skipping due to homozygous donor splice site mutation of a TSH $\beta$-subunit gene. J Clin Endocrinol Metab 87:336-339 